\title{
New prescribing powers for Polish nurses and midwives in relation to ICNP ${ }^{\circledR}$
}

\section{Hanna Grabowska ${ }^{1,2}$, Władysław Grabowski ${ }^{1}$, Agata Flis ${ }^{1}$, Aleksandra Gaworska-Krzemińska ${ }^{1,2}$}

\author{
${ }^{1}$ Katedra Pielęgniarstwa, Gdański Uniwersytet Medyczny \\ ${ }^{2}$ Rada ds. e-Zdrowia w Pielęgniarstwie przy Centrum Systemów Informacyjnych Ochrony Zdrowia w Warszawie \\ Address for correspondence: Hanna Grabowska, Katedra Pielęgniarstwa, Gdański Uniwersytet Medyczny, ul. Dębinki \\ 7, 80-211 Gdańsk, tel./fax 0485834919 80, hanna.grabowska@gumed.edu.pl
}

\section{Abstract}

In January 2016 Polish nurses and midwives were granted new powers to prescribe medications and food of special purposes, as well as to issue referrals for several diagnostic tests and prescriptions for reimbursed medical products.

The aim of this paper is to present the possibility to describe the process of prescribing medications using the international language of nursing practice ICNP $®$.

International Classification for Nursing Practice (ICNP®) is a unified glossary of referential terms for nursing practice that is recommended by the most important medical and professional organisations in Poland and all over the world.

Numerous ICNP ${ }^{\circledR}$ terms, which do not only meet international criteria but can - and should -become the primary communication tool for everyday nursing practice of Polish nurses and midwives are an alternative to often random, traditional and intuitive expressions describing nursing and midwifery activities related to widely understood process of prescribing medications.

\section{Key words: prescriptions for medications, nurses, midwives, classification}

Stowa kluczowe: ordynowanie leków, pielęgniarka, położna, klasyfikacja

Ministerstwo Nauki i Szkolnictwa Wyższego
Przygotowanie do wydania elektronicznego finansowane w ramach umowy 641/P-DUN/2018 ze środków Ministra Nauki i Szkolnictwa Wyższego przeznaczonych na działalność upowszechniającą naukę.

\section{Introduction}

On the strength of the Act of 22 June 2014 amending the Act on Professions of Nurse and Midwife and some other acts (Journal of Laws of 2014, No. 1136), since $1^{\text {st }}$ of January 2016 nurses and midwives have been given the power to prescribe medications (including specified active ingredients, excepted of medicines that include substances acting very intensively, mind-expanding and psychotropic drugs), food of special purposes, issue re- ferrals for several diagnostic tests, as well as prescriptions for reimbursed medical products. Depending on their competencies, nurses and midwives may prescribe medications to patients on their own or issue prescriptions as a follow-on of a therapy prescribed by a physician [1-3].

It is worth to emphasise that the powers concern mainly those nurses and midwives who perform public health care services in a community of their patients (i.a. as a long-term/palliative/hospice care) $[1,3]$. 
Polish dictionary defines a term 'prescribing' (pol. ordynowanie) as both prescribing and administering drugs, but also as providing patients with medical advice and treatment [4]. This term, however, does not have a legal definition, i.e. resulting from the Act of 15 July 2011 on Professions of Nurse and Midwife (Journal of Laws of 2014, No. 1435) with later amendments (Public Procurement Law) $[1,3]$.

In general, this term is considered as prescribing drugs [3], regarded as a complex process that consists of a few stages. These may include: making a decision on the justifiability of using a certain medication (on the basis of clinical judgement/physical examination conducted by a nurse/midwife), choice of an optimal medication, its dozing, prescribing and monitoring its effectiveness and possible side-effects of the chosen therapy, as well as education of patients and their families concerning the way of medication use and potential adverse effects [3] (Figure 1).

The aim of this paper is to present the possibility to describe the process of prescribing medications in the international language of nursing practice ICNP®.

International Classification for Nursing Practice (ICNP $\AA)$ belongs to a family of taxonomies of World Health Organisation (WHO) and is recommended by international and domestic organisations, especially International Council of Nurses (ICN) - being a part of the ICN eHealth Programme, European Federation of Nurses Associations (EFN), ICN - Accredited ICNP® Research and Development Centres, Polish Nurses Association, Centre of Information Systems in Health Care, including the Council on eHealth Matters in Nursing, Ministry of Health and Head Chamber of Nurses and Midwives [5-9].

ICNP ${ }^{\circledR}$ is a unified glossary of referential terms for nursing practice which meets all requirements of International Organization for Standards (ISO) and is modelled

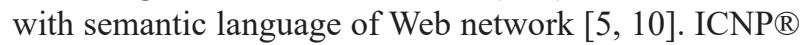
version of 2015 (translated into Polish) consists of over four thousands of terms, including 805 terms in diagnosis/outcome code (DC) and 1019 nursing interventions (IC), which may be complemented by terms coming from other 7 axes, i.e.: $\mathrm{F}$ - Focus; $\mathrm{C}$ - Client; L - Location; T - Time; M - Means; J - Judgement), A - Action $[5,6,10]$. Each term is assigned with a unique identification code that consists of 8 digits. The update version, approved in 2017 during the ICN Congress in Barcelona, was enriched with alternate terms [11].

It seems justifiable that the profession of nurses and midwives in Poland should want and be able to use ICNP $\AA$, discerning and appreciating its advantages and profits resulting from its implementation. All the more, since the everyday language used in discussions, medical documentation, numerous papers and handbooks for nurses, midwives and students is highly mixed, the same actions are described in various ways which can cause numerous controversies, doubts and lead to difficulty in achieving final agreement or lack of it. New prescribing

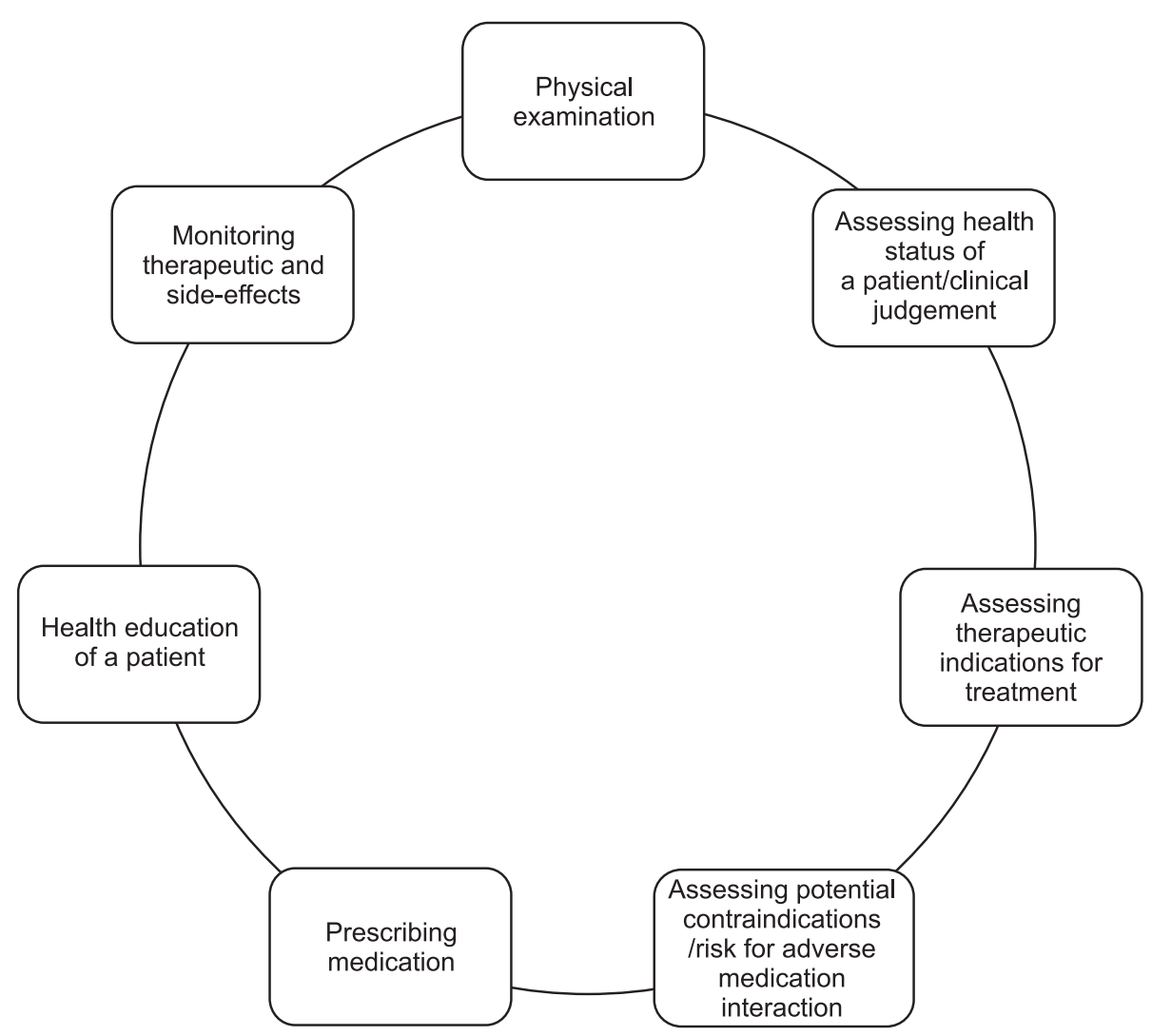

Figure 1. Process of prescribing medications in nursing/midwifery practice.

Source: Own study. 
powers and access to the unified, referential glossary of ICNP ${ }^{\circledR}$ are not only a challenge for the profession of nurses and midwives, but also a chance for development of the profession and its representatives.

Commonly used, traditional terms concerning questions presented in this paper are: "Involvement of a nurse/ midwife in therapy/pharmacological treatment/treatment procedures/pharmacotherapy [...] by administering prescribed medications/administering medications/administering medications according to physician's orders/ medical order/medication administering on the basis of an order/administering medication according to the card of orders" [12-16].

All terms mentioned above may be alternated by numerous terms from ICNP $\AA$. One of them is the intervention "Managing Medication (10011641)". However, it is worth emphasising that "managing [10011625]" (axis: A) is defined as "being in charge of and bringing order to somebody or something" [11]. This intervention is an example of a superordinate intervention, including detailed interventions, i.e.: "administering medication
[10025444]", "handling medication [10040708]", and "prescribing medication [10015523]" [11].

"Administering[10001773]" (axis: A) - according to a definition from ICNP $®$ - is a type of distributing, based on providing or applying something, while "prescribing [10015510]" (axis: A) is defined as "designating the use of a remedy or regiment, directing the administration of a remedy or treatment" [11].

The intervention "administering medication" in many cases may be insufficient in a documentation of actions instigated by a nurse or a midwife. However - in justified cases, especially related to the way of using a medication - ICNP® classification floats additional terms describing more detailed interventions, e.g.: "Administering Intramuscular Medication (10045827)/Vaginal [10045858]/Intravenous [10045836]/Subcutaneous [10045843]/Inhalant [10046579]/Intracutaneous [10045815]/Medication And Solution [10001804]/After Interpreting Arterial Blood Gas Result [10001794]" [11]. It is illustrated in Figure 2.

The taxonomy also includes interventions that allow nurses/midwives for description and documentation of

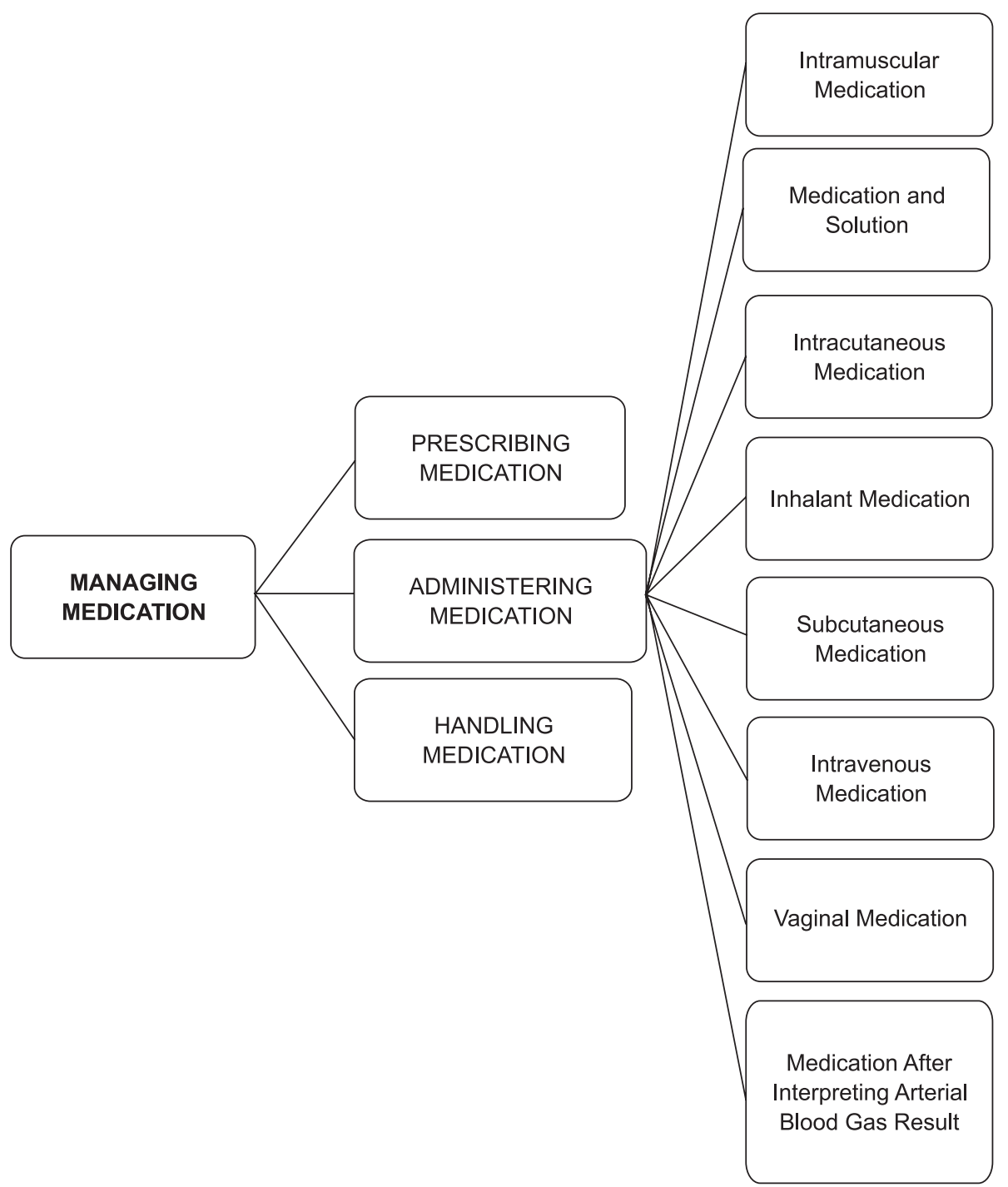

Figure 2. Scope of specification of $I C N P ®$ intervention "Managing Medication".

Source: Own study. 
type of treatment/medication/cure that they administer. Some of them are: "administering antibiotic [10030383], insulin [10030417], pain medication [10023084]", or "administering nutritional supplements [10037037]" [11]. All alternatives included in the current version of ICNP® are illustrated in Figure 3.

Papers for students of nursing, professionally active nurses and midwives include some notations emphasising the significance of getting information about "pharmacological therapy" over to patients, especially concerning "action/effects of administered medication/dozes/necessity of following the schedule of usage, recognising basic symptoms of side-effects, possible symptoms of side-effect and adverse effect of medication and proper reaction in case of observing those effects" [11].

Also this aspect may be successfully described by the referential language of ICNP $\AA$, namely by interventions (IC) that it includes, for example: assessing the patient's competencies concerning the process of taking medications (IC: “Assessing Knowledge Of Medication Regime [10039039]"), teaching the patient and/or their caretakers (IC: "Teaching About Medication [10019470]/Teaching About Medication Handling [10040712]/Teaching About Medication Side Effects [10044614]"), and finishing with evaluating the outcomes of health education (IC: "Evaluating Psychosocial Response To Instruction About Medication [10007130]") [11].

The term "teaching [10019502]", which comes from the axis: action, signifies informing and "giving systematic information to somebody about health related subjects" [11]. During the process of teaching patients and their families, various didactic measures might turn up to be necessary which can be described by terms from Classification, e.g. intervention "Providing Instructional Material [10024493]", which - depending on individual needs - can be specified by using IC: "Providing Medication List [10042697], Providing Medication Schedule [10043185]" or "Providing Pillbox[10043003]/ Providing Talking Pillbox [10043589]" [11]. "Providing [10015935]" according to ICNP® definition (axis: A) means 'making something ready for somebody' [11].

ICNP ${ }^{\circledR}$ includes also terms concerning: "demonstrating [10005713]" (axis: A), interpreted as "showing in publicly observable behavior", including i.e. IC: "Demonstrating Medication Administration [10024354]" or "Demonstrating Subcutaneous Injection Technique [10021695] [11] (e.g. insulin or low molecular weight heparin preparations) and also promoting [10015801]" (axis: A), that is "helping to begin or advance something for somebody" (IC: "Promoting Medication Adherence [10038051], Promoting Medication Adherence Using Pillbox [10021703]") [11].

In accordance with the provisions of the Act, nurses and midwives may prescribe medications only after carrying out a personal physical examination of a patient [13], which can be also described and documented with ICNP® terms, especially IC: "Physical Examination [10032258]" or additional "Diagnostic Testing [10031140]", “Assessing Physiological Status [10030694]/Psychological Status [10030734]/Social Status [10030752]" [11]. It is obvious that conclusions from conducted analysis of patients' status should be meticulously reported in a medical documentation of a patient [3].

Intervention "Reporting Test Result [10016839]" is an illustration of the aspect ("reporting [10016771]"/axis: A - means 'making an account or summation of events or observations'), and also - in case of a nurse's/midwife's doubts about their clinical judgement of a patient and/ or justified necessity to prescribe a specified medication/ referral to a specialist - "Reporting Status To Interprofessional Team [10042645]" [11].

Another important element of prescribing medications by nurses and midwives is both conducting a systematic assessment of potential side-effects that may occur during treatment and monitoring symptoms that have already occurred, and which with a great probability suggest side-effects of the pharmacotherapy. Also here ICNP ${ }^{\circledR}$ Classification may be helpful, as there are terms that perfectly illustrate those questions, i.e. IC: "Assessing Risk For Adverse Medication Interaction ([10045940],
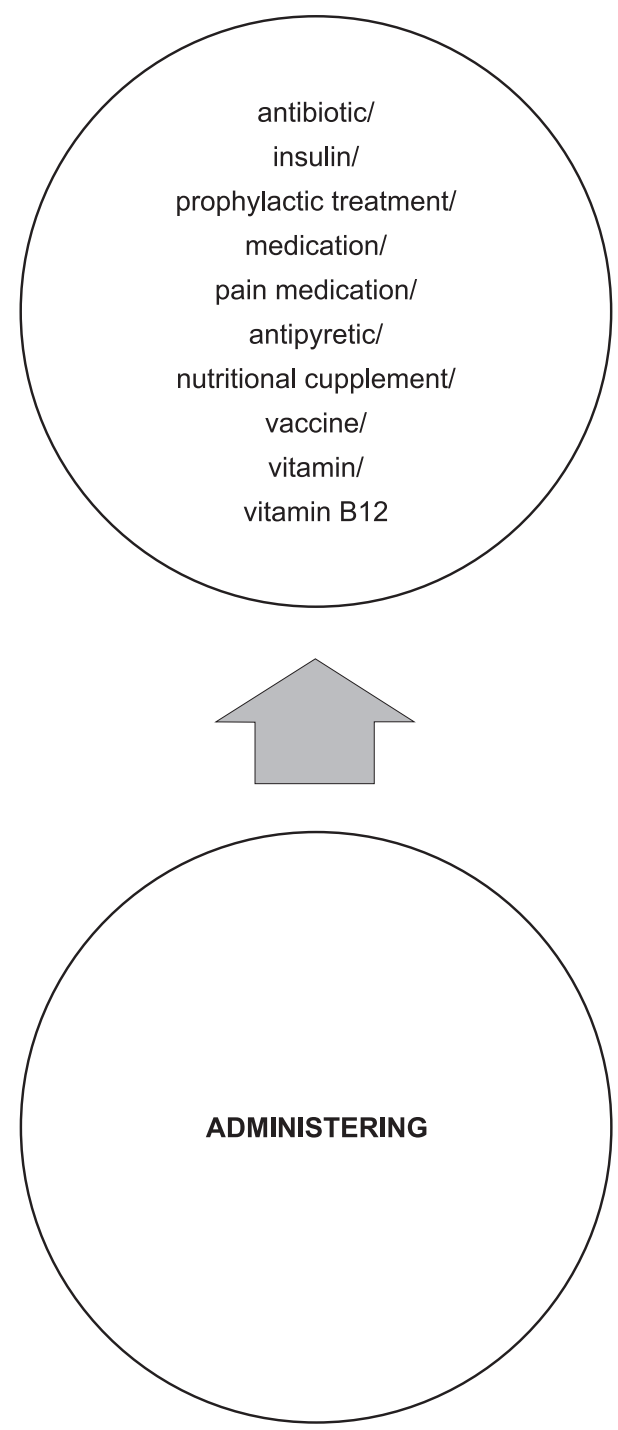

Figure 3. Examples of $I C N P \AA$ interventions related to administering.

Source: Own study. 
Assessing Medication Side Effect [10039087], but also Monitoring Response To Treatment [10032109], Monitoring Medication Side Effect [10043884]" and - in case of their occurrence - "Managing Medication Side Effect [10021837]" [11].

It is also worth mentioning that the term "assessing [10002673]" (axis: A) is defined as "estimating the size, quality and significance of something", while "monitoring [10012154]" (axis: A) is "scrutiny of somebody or something on repeated or regular occasions" [11]. All these actions carried out by medical staff which are related to assessing and monitoring status of a patient to whom a specified pharmacological treatment (and not only) was prescribed allow for "evaluating [10007066]" (axis: A), i.e. "continuous process to measure progress or the extent to which set goals have been met" (IC: "Evaluating Response To Treatment [10044195]" and specified by IC: "evaluating response to medication [10007182]/ fluid therapy [10007176])" [11].

Gathering information about a patient, a nurse/midwife should also show interest in the degree of obeying recommendations of the therapy and guidelines that were provided to a patient. While documenting the actions carried out in this area, the personnel may use the ICNP ${ }^{\circledR}$ and its interventions, such as: "Evaluating Treatment Regime [10031268]/Adherence To Treatment Regime [10044153], Assessing Adherence To Therapeutic Regime [10045889], Assessing Adherence To Medication Regime [10037852], Assessing Attitude Toward Treatment Regime [10024205], Monitoring Medication Adherence [10043878]" or "Assessing Medication Supply [10022912]" [11].
Therapeutic process often requires consultations and active interdisciplinary cooperation (mainly with doctors and pharmacists) and also cooperation with patients and their families. ICNP $®$ is helpful also in this field, as it includes several interventions concerning "consulting [10005017]" (axis: A) meaning 'seeking advice, obtaining information sharing ideas and considering jointly', and also collaborating [11]. It may include IC: "Consulting Health Care Provider [10005029]/Consulting Health Care Provider About Medication Side Effects [10043233]" or "Consulting Pharmacist About Generic Medication [10043159]" [11]. However the aspect of "collaborating [10004542]" (axis: A), defined as "working jointly with one or more people" [11] is described i.a. by interventions presented in Figure 4.

\section{Summary}

Since the prescribing powers for Polish nurses and midwives are relatively new and often arouse ambivalent emotions and opinions, both in medical profession [17-21] and among patients [19, 22] - it may be assumed that within the time - as the experiences from other countries show [3, 23, 24] - those competencies will be passed on the increasing number of profession of nurses/midwives. However, before they become an element of everyday practice, these powers will require a support - in a broad sense. This should involve not only a legislative support, but also an open and trustful attitude of patients, medical staff and especially nurses and midwives themselves, who should use assigned powers and privileges in a professional and responsible manner.

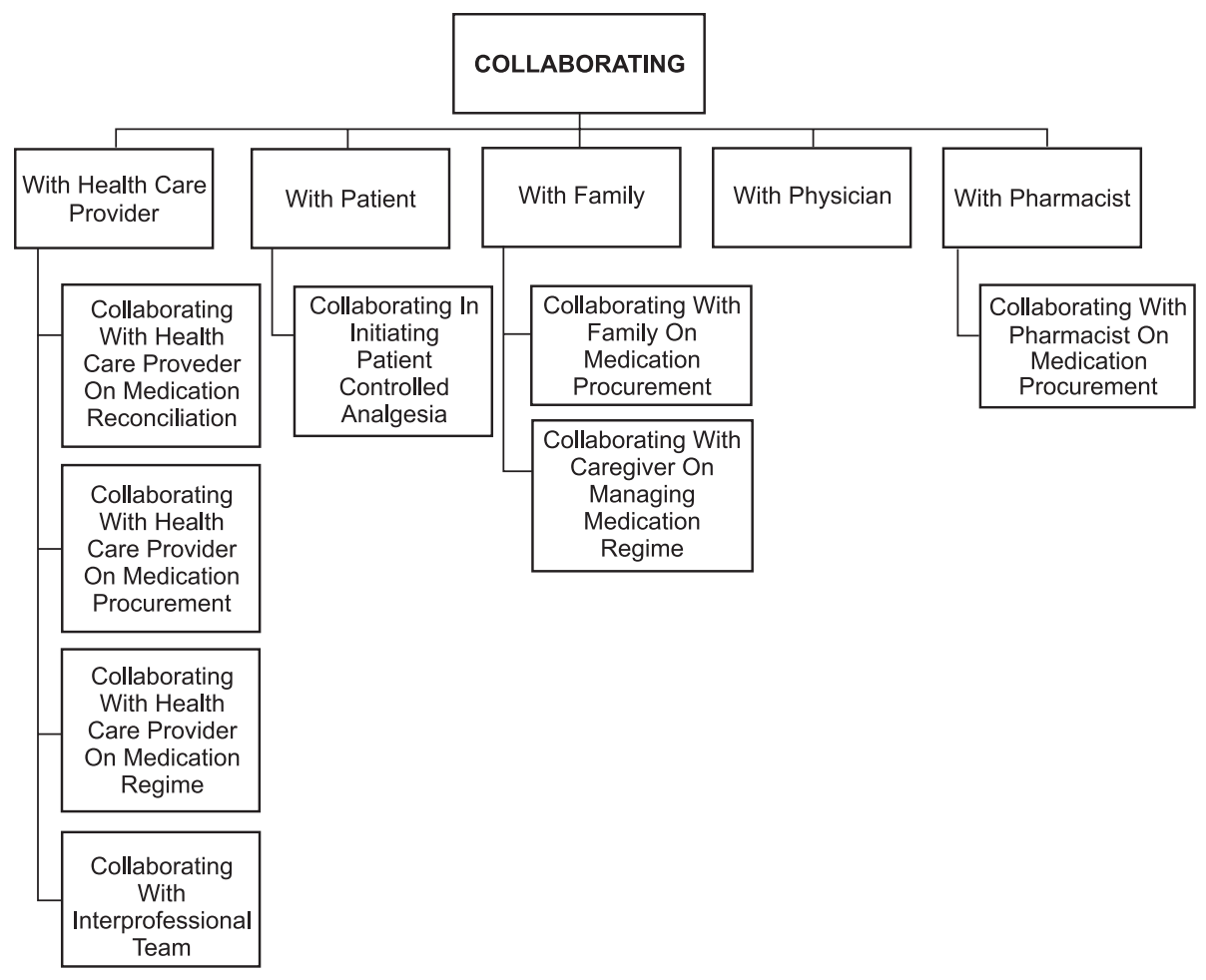

Figure 4. Some ICNP ${ }^{\circledR}$ interventions aimed at "Collaborating".

Source: Own study. 


\section{NURSING DIAGNOSIS}

- Medication Side Effect [10022626]

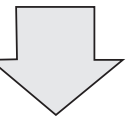

\section{NURSING INTERVENTIONS}

- Monitoring Medication Side Effect [10043884]

- Assessing Medication Side Effect [10039087]

- Teaching About Medication Side Effects [10044614]

- Managing Medication Side Effect [10021837]

- Consulting Health Care Provider About Medication Side Effects [10043233]

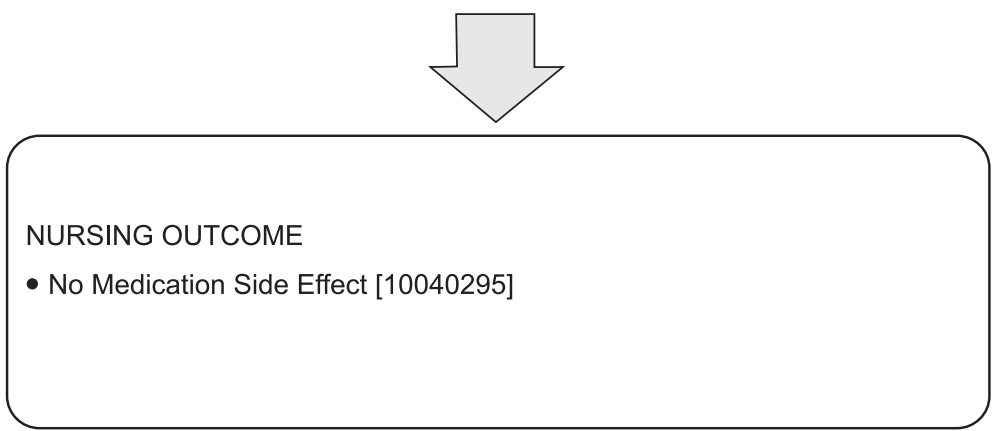

Figure 5. Example of a nursing plan using $I C N P^{\circledR}$.

Source: Own study.

A separate aspect, which is still closely related to these competences of nurses and midwives, is the necessity to use a unified, professional terminology. It is important in both verbal communication and also in the process of documenting all taken actions - especially in electronic documentation. The international, referential terminology included in ICNP® should become an indispensable and attractive tool for all concerned with this subject. An example of its use is presented in Figure 5.

\section{References}

1. Zimmermann A., Cieplikiewicz E., Flis A., Preskrypcja pielegniarska: analiza polskiego stanu prawnego, "Farmacja Polska” 2017; 73 (4): 226-230.

2. Dominiak I., Sutkowska B., Aspekty prawne i odpowiedzialność zawodowa, in: Dominiak I., Gaworska-Krzemińska A., Kilańska D. (eds.), Ordynowanie leków i wypisywanie recept. Przewodnik dla pielegniarek i położnych Edumetriq, Sopot 2016: 219-248.

3. Zimmermann A., Gaworska-Krzemińska A., Cieplikiewicz E., Flis A., Ordynacja i preskrypcja pielęgniarska w Polsce, "Problemy Pielęgniarstwa" 2015; 23 (4): 551-556. DOI: 10.5603/PP.2015.0090.

4. https://sjp.pwn.pl/sjp/ordynowac;2569926.html (accessed: 13.08.2017).
5. Kilańska D., Grabowska H., ICNP® - podstawowe rozwiąania, strategia, praktyka pielegniarska (zarzadzanie wiedza), edukacja i miejsce $w$ systemie informatycznym ochrony zdrowia, in: Kilańska D. (ed.), Międzynarodowa Klasyfikacja Praktyki Pielegniarskiej. ICNP® w praktyce pielęgniarskiej, Wydawnictwo Lekarskie PZWL, Warszawa 2014: 49-97.

6. http://www.icn.ch/what-we-do/international-classification-for-nursing-practice-icnpr/ (accessed: 13.08.2017).

7. https://www.csioz.gov.pl/interoperacyjnosc/klasyfikacje/ (accessed: 13.08.2017).

8. http://pielegniarstwo.umed.lodz.pl/?page_id=3784 (accessed: 13.08.2017).

9. http://www.ptp.na1.pl/pliki/nurse_prescribing/EFN\%20 Letter\%20-\%20Nurse \%20Prescribing\%20in\%20Poland \%2013\%20June\%202014.pdf (accessed: 13.08.2017).

10. Bartz C.C., Kim T.Y., Kilańska D.M., Standard terminology for nursing, "Problemy Pielęgniarstwa" 2017; 25 (2): 108-111. DOI: 10.5603/PP.2017.0017.

11. ICNP Browser; http://www.icn.ch/ICNP-Browser-NEW. html (accessed: 13-15.08.2017).

12. Talarska D., Zozulińska-Ziółkiewicz D. (eds.), Pielęgniarstwo internistyczne, Wydawnictwo Lekarskie PZWL, Warszawa 2017.

13. Kaszuba D., Nowicka A. (eds.), Pielegniarstwo kardiologiczne, Wydawnictwo Lekarskie PZWL, Warszawa 2014. 
14. Jurkowska G., Łagoda K. (eds.), Pielegniarstwo internistyczne, Wydawnictwo Lekarskie PZWL, Warszawa 2014.

15. Kózka M., Płaszewska-Żywko L. (eds.), Modele opieki pielęgniarskiej nad chorym dorostym. Podręcznik dla studiów medycznych, Wydawnictwo Lekarskie PZWL, Warszawa 2010.

16. Kędziora-Kornatowska K., Muszalik M., Krajewska-Kułak E., Wrońska I. (eds.), Repetytorium z pielęgniarstwa. Podręcznik dla studiów medycznych, Wydawnictwo Lekarskie PZWL, Warszawa 2014.

17. Bartosiewicz A., Binkowska-Bury M., Marć M., Januszewicz P., Gotowość pielęgniarek do ordynowania leków i wypisywania recept, "Problemy Pielęgniarstwa" 2016; 24 (2): 91-97. DOI: 10.5603/PP.2016.0015.

18. Binkowska-Bury M., Bartosiewicz A., Marć M., Januszewicz P., Nowe ustawodawstwo dotyczace możliwości samodzielnego ordynowania leków $i$ wystawiania recept przez pielegniarki w Polsce: poglady lekarzy podstawowej opieki zdrowotnej, "Medycyna Rodzinna" 2016; 19 (2): 47-54.

19. Binkowska-Bury M., Więch P., Bazaliński D., Marć M., Bartosiewicz A., Januszewicz P., Nurse prescribing in Poland: Opinions expressed by primary care doctors, nurses, and patients, "Medicine" (Baltimore) 2016; 95 (33): e4506. DOI: 10.1097/MD.0000000000004506.

20. Zarzeka A., Panczyk M., Ścieglińska B., Belowska J., Iwanow L., Gotlib J., Attitudes of ward nurses towards extending professional powers with respect to writing out prescriptions and independent referrals for diagnostic tests
- a preliminary qualitative study. [Postawy pielegniarek oddziałowych wobec rozszerzenia uprawnień zawodowych $w$ zakresie wystawiania recept oraz samodzielnego kierowania na badania diagnostyczne - wstęne badanie jakościowe], "Pielęgniarstwo Polskie" 2015; 4 (58): 409-414.

21. Zarzeka A., Panczyk M., Żmuda-Trzebiatowska H., Belowska J., Samoliński Ł., Iwanow L., Gotlib J., Nurse prescribing. Knowledge and attitudes of polish nurses in the eve of extending their professional competences: crosssectional study, "Acta Poloniae Pharmaceutica - Drug Research" 2017; 74 (3): 1031-1038.

22. Binkowska-Bury M., Bartosiewicz A., Marć M., Januszewicz P., Opinia pacjentów Podstawowej Opieki Zdrowotnej na temat ordynowania wybranych leków $i$ wystawiania recept przez pielegniarki, "Hygeia Public Health” 2016; 51 (2): 161-170.

23. Kowalska I., Sagan A., Mokrzycka A., Zabdyr-Jamróz M., The first attempt to create a national strategy for reducing waiting times in Poland: will it succeed?, "Health Policy" 2015; 119 (3): 258-263. DOI: 10.1016/j.healthpol.2014.12.010.

24. Bartosiewicz A., Binkowska-Bury M., Januszewicz P., Możliwość przepisywania recept przez pielęniarki i położne - stan prawny w Polsce i ogólny przeglad sytuacji na świecie, "Przegląd Medyczny Uniwersytetu Rzeszowskiego i Narodowego Instytutu Leków w Warszawie" 2015; 13 (3): 290-305. DOI: 10.15584/przmed.2015.3.9. 